\title{
Pengaruh Aktivitas, Profitabilitas terhadap Pertumbuhan Laba (Studi Pada Perusahaan Otomotif dan Komponen yang Terdaftar di Bursa Efek Indonesia Tahun 2015-2019)
}

\author{
*Dwi Lathifah Sari, Siti Rosyafah, Masyhad \\ Jurusan Akuntansi Fakultas Ekonomi dan Bisnis \\ Universitas Bhayangkara Surabaya, Indonesia
}

DOI: 10.46821/equity.v1i1.205

\begin{abstract}
ABSTRAK
Perusahaan memiliki tujuan utama yaitu memperoleh dan meningkatkan laba. Laba yang diperoleh perusahaan akan digunakan untuk berbagai kepentingan, salah satunya digunakan untuk meningkatkan kesejahteraan perusahaan atas produk atau jasa yang dijual. Penelitian ini bertujuan untuk mengetahui pengaruh aktivitas, profitabilitas terhadap pertumbuhan laba pada perusahaan otomotif dan komponen yang terdaftar di Bursa Efek Indonesia. Penelitian ini menggunakan pendekatan kuantitatif dengan pengumpulan data menggunakan financial statement. Populasi penelitian ini adalah perusahaan otomotif dan komponen yang terdaftar di Bursa Efek Indonesia selama periode 2015-2019. Teknik pengambilan sampel yang digunakan adalah teknik purposive sampling. Metode analisa data yang digunakan adalah analisa regresi linier berganda dengan uji hipotesis yaitu uji $F$ dan uji t. Hasil dari penelitian ini menunjukkan bahwa Aktivitas, Profitabilitas berpengaruh secara simultan dan parsial terhadap pertumbuhan laba. Variabel Profitabilitas berpengaruh dominan terhadap Pertumbuhan Laba.
\end{abstract}

Kata kunci: Aktivitas, Profitabilitas, Pertumbuhan Laba

\begin{abstract}
The company has the main objective of obtaining and increasing profits. The profits obtained by the company will be used for various purposes, one of which is used to improve the company's welfare for the products or services sold. This study aims to determine the effect of activity, profitability on profit growth in automotive and component companies listed on the Indonesia Stock Exchange. This study uses a quantitative approach with data collection using financial statements. The population of this study are automotive and component companies listed on the Indonesia Stock Exchange during the 2015-2019 period. The sampling technique used is purposive sampling technique. The data analysis method used is multiple linear regression analysis with hypothesis testing, namely the F test and t test. The results of this study indicate that activity, profitability have a simultaneous and partial effect on profit growth. Profitability variable has a dominant effect on Profit Growth.
\end{abstract}

Keywords: Activity, Profitability, Profit Growt

*Corresponding Author:

Email: mylatifa12@gmail.com 


\section{PENDAHULUAN}

Perusahaan memiliki tujuan utama yaitu memperoleh dan meningkatkan laba. Perkembangan dunia usaha semakin menuntut perusahaan berpacu untuk mengatasi persaingan yang semakin ketat dan kompleks, sehingga perusahaan dituntut harus mampu melaksanakan pengelolaan secara efektifdan efisien agar dapat mencapai tujuan yang diharapkan. (Enny Istanti, 2020) Laba yang diperoleh perusahaan akan digunakan untuk berbagai kepentingan, salah satunya digunakan untuk meningkatkan kesejahteraan perusahaan atas produk atau jasa yang dijual. Saat ini, persaingan antar perusahaan dalam menciptakan laba semakin tinggi. Perusahaan berupaya terus meningkatkan laba agar dapat mempertahankan kelangsungan hidupnya. Perusahaan dituntut untuk dapat mengungguli persaingan dan mampu bertahan dalam siklus kehidupan bisnis dalam jangka waktu yang panjang.

Perusahaan menggunakan kinerja keuangan sebagai alat ukur untuk mengukur tingkat keberhasilan dalam menghasilkan laba bersih yang optimal. Selain itu perusahaan juga memerlukan pengelolaan yang baik yang mampu menghasilkan pertumbuhan laba yang terus meningkat setiap periode. Semakin tinggi laba yang dihasilkan perusahaan maka menunjukkan kinerja perusahaan yang efektif dan efisien. Namun pada kenyataannya, laba perusahaan terkadang mengalami penurunan. Oleh karena itu, diperlukan analisis laporan keuangan untuk memprediksi laba di tahun mendatang. Dalam menganalisis laporan keuangan untuk memprediksi laba, ada banyak rasio keuangan yang bisa digunakan, misalnya dari utang, dari penjualan dan dari investasi yang ditanamkan.

Puspasari, Suseno, \& Sriwidodo (2017) menyatakan bahwa analisis rasio keuangan dapat membantu para pelaku bisnis dan pihak pemerintah dalam mengevaluasi keadaan keuangan perusahaan masa lalu, sekarang dan memproyeksikan hasil atau laba yang akan datang. Selain itu, rasio keuangan dapat dipakai sebagai sistem peringatan awal terhadap kemunduran kondisi keuangan dari suatu perusahaan.

Perusahaan Otomotif di Bursa Efek Indonesia sebagai bahan penelitian di dasari oleh karena perusahaan otomotif beberapa tahun terakhir mengalami perkembangan pesat. Selain itu, industri otomotif saat ini sedang menghadapi persaingan yang tinggi serta selalu mengikuti perkembangan teknologi yang cepat dengan memproduksi kendaraan bermotor yang beragam.

Berdasarkan penjelasan diatas maka permasalahan yang akan diteliti meliputi: (1) Apakah Aktivitas, Profitabilitas secara parsial berpengaruh terhadap pertumbuhan laba pada perusahaan otomotif dan komponen yang terdaftar di Bursa Efek Indonesia periode 2015-2019? (2) Apakah Aktivitas, Profitabilitas secara simultan berpengaruh terhadap pertumbuhan laba pada perusahaan otomotif dan komponen yang terdaftar di Bursa Efek Indonesia periode 20152019? (3) Manakah diantara variabel Aktivitas, Profitabilitas yang mempunyai 
pengaruh dominan terhadap pertumbuhan laba pada perusahaan otomotif dan komponen yang terdaftar di Bursa Efek Indonesia periode 2015-2019?

\section{LANDASAN TEORI}

\section{Rasio Aktivitas (Activity Ratio)}

Menurut Kasmir (2018:172), "rasio aktivitas merupakan rasio yang digunakan untuk mengukur efektivitas perusahaan dalam menggunakan aktiva yang dimilikinya".

\section{Total Assets Turn Over (TATO)}

Menurut Kasmir (2018:185),“Total Assets Turn Over merupakan rasio yang digunakan untuk mengukur berapa jumlah penjualan yang diperoleh dari tiap aktiva".

\section{Fixed Assets Turn Over (FATO)}

Menurut Kasmir (2018:184), "fixed assets turn over merupakan rasio yang digunakan untuk mengukur berapa kali dana yang ditanamkan dalam aktiva tetap berputar dalam satu periode.

\section{Rasio Profitabilitas}

Menurut (Kasmir, 2016), "Rasio profitabilitas merupakan rasio untuk menilai kemampuan perusahaan dalam mencari keuntungan".

\section{Return On Asset (ROA)}

Menurut Hery (2016:106), "ROA merupakan rasio yang menunjukkan hasil atas pengunaan aset perusahaan dalam menciptakan laba bersih".

\section{Return On Equity (ROE)}

Menurut Kasmir (2018:204), "hasil pengembalian ekuitas atau return on equity merupakan rasio yang menunjukkan hasil pengembalian ekuitas atau rentabilitas modal sendiri”.

\section{Return On Investment (ROI)}

Menurut Kasmir (2018:201), "hasil pengembalian investasi atau return on investment merupakan rasio yang menunjukkan hasil atas jumlah aktiva yang digunakan dalam perusahaan".

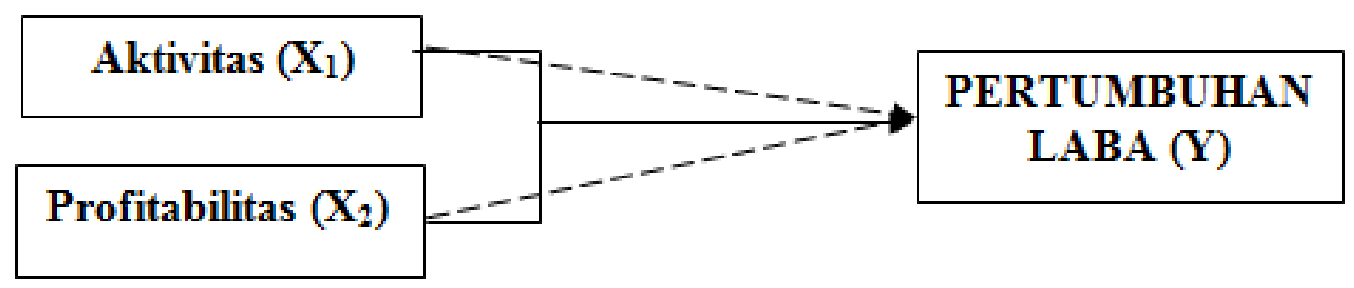

Gambar 1. Kerangka Konseptual 
Gross Profit Margin (GPM)

Rasio ini menggambarkan laba kotor yang dapat dicapai setiap rupiah penjualan. Semakin besar rasionya akan semakin baik kondisi keuangan perusahaan.

\section{Net Profit Margin (NPM)}

Net Profit Margin (NPM) menunjukkan berapa besar persentase pendapatan bersih yang diperoleh dari setiap penjualan. Marjin Laba Bersih (Net Profit Margin) Menurut Hery(2015:198-199), "Marjin laba merupakan rasio yang digunakkan untuk mengukur besarnya presentase laba bersih atas penjualan bersih".

\section{Pertumbuhan Laba}

Menurut Harahap (2016:310) , "Pertumbuhan laba merupakan suatu rasio yang menunjukkan kemampuan perusahaan dalam meningkatkan laba bersih dibanding tahun lalu.

\section{Hipotesis Penelitian}

Berdasarkan rumusan masalah, tujuan penelitian, landasan teori, yang diekmukakakn diatas, maka hipotesis yang diperoleh :

$\mathrm{H}_{1}$ : Aktivitas, Profitabilitas berpengaruh secara parsial terhadap pertumbuhan Laba.

$\mathrm{H}_{2}$ : Aktivitas, Profitabilitas berpengaruh secara simultan terhadap Pertumbuhan Laba.

$\mathrm{H}_{3}$ : Profitabilitas berpengaruh secara dominan terhadap pertumbuhan laba.

\section{METODE PENELITIAN}

\section{Lokasi Dan Waktu Penelitian}

Penelitian ini dilakukan pada Perusahaan Otomotif dan Komponen yang terdaftar di Bursa Efek Indonesia (BEI) periode 2015-2019 yang dilakukan secara online dari website resmi $w w w . i d x$.co.id. Waktu penelitian ini adalah pada bulan Februari 2021 hingga Januari 2022.

\section{Teknik Pengumpulan Data}

\section{Jenis Data}

Jenis data yang digunakan lama penelitian ini adalah data sekunder. Data sekunder merupakan data penelitian yang diperoleh peneliti secara tidak langsung atau melalui perantara (diperoleh dan dicatat oleh pihak lain). Menurut sifatnya data dalam penelitian ini termasuk data Kuantitatif.Data kuantitatif adalah data berupa angka atau besaran tertentu yang sifatnya pasti. Jenis data yang digunakan dalam penelitian ini adalah data kuantitatif. Kuantitatif adalah data yang berbentuk angka atau data kualitatif yang diangkakan. (Sugiyono, 2015:329). 


\section{Sumber Data}

Sumber data yang digunakan dalam penelitian ini diperoleh dari data sekunder laporan keuangan tahun periode 2015-2017 yang didapatkan dari BEI (www.idx.co.id).

Data sekunder yaitu penelitian yang dilakukan dengan cara memperoleh data dengan membaca buku yang ada di perpustakaan yang berhubungan dengan masalah di atas. Hal ini akan digunakan sebagai landasan teori untuk memecahkan permasalahan.

\section{Pengumpulan data}

Dalam penelitian ini peneliti mengambil data dari financial statement pada Perusahaan Otomotif dan Komponen 2015-2019 dan dalam penelitian ini peneliti mengumpulkan data dari beberapa buku dan jurnal penelitian terdahulu.

\section{Teknik Analisis Data dan Uji Hipotesis}

\section{Statistik Deskriptif}

Menurut Sugiyono (2017:147), "Statistik Deskriptif adalah statistik yang digunakan untuk menganalisis data dengan cara mendeskripsikan atau menggambarkan data yang telah terkumpul sebagaimana adanya tanpa bermaksud membuat kesimpulan yang berlaku untuk umum atau generalisasi”

\section{Pengujian Hipotesis}

\section{Uji Regresi Linear Berganda}

Teknik analisis regresi yang digunakan dalam penelitian ini adalah regresi linear berganda. Regresi linear berganda menurut Sugiyono(2016), "digunakan oleh peneliti bila penelitian bermaksud meramalkan bagaimana keadaan (naik turunnya) variabel terikat, bila dua variabel bebas sebagai faktor prediktor dimanipulasi”. Model penelitian ini adalah:

$$
\begin{aligned}
& \mathrm{Y}=\mathrm{a}+ \\
& \text { Keterangan }: \\
& \mathrm{Y} \quad=\text { Pertumbuhan Laba } \\
& \mathrm{a} \quad=\text { Konstanta } \\
& \beta 1 \beta 2=\text { Koefisien Regresi } \\
& \mathrm{X} 1 \quad=\text { Rasio Aktivitas } \\
& \mathrm{X} 2 \quad=\text { Rasio Profitabilitas } \\
& \mathrm{e} \quad=\text { error }
\end{aligned}
$$

\section{Koefisien Determinasi $\left(\mathbf{R}^{2}\right)$}

Koefisien determinasi disebut sebagai koefisien penentu, karena varians yang terjadi pada variabel dependen dapat dijelaskan melalui varians yang terjadi pada variabel independen. 
Uji Simultan F (Uji F)

Uji statistik F pada dasarnya menunjukkan apakah semua variabel bebas atau bebas yang dimasukkan ke dalam model memiliki pengaruh bersama-sama terhadap variabel terikat (Ghozali, 2016:96).

\section{Uji Parsial t (Uji t)}

Uji statistik t pada dasarnya menunjukkan seberapa jauh pengaruh satu variabel penjelas/independen secara individual dalam menerangkan setiap variabel terikat (Ghozali, 2016:97).

\section{Pengukuran Variabel Dominan}

Untuk mengetahui variabel mana yang dominan diantara variabel bebasyang terdiri dari likuiditas, solvabilitas dan aktivitas berpengaruh terhadapprofitabilitas perusahaan, maka dilakukan dengan melihat rangking koefisienregresi yang distandartkan $(\beta)$ atau standartdized of coefficient beta yang tertinggi dari setiap variabel.

\section{HASIL DAN PEMBAHASAN}

\section{Uji Kualitas Data}

\section{Analisis Statistik Deskriptif}

Hasil Statistik Deskriptif disajikan dalam bentuk Tabel 1. Berdasarkan data dari Tabel 1 dapat dijelaskan bahwa Variabel Aktivitas mempunyai Nilai minimum 0,51 dan nilai maksimum 5,56. Rata - Rata Aktivitas 2,1078 dengan standar deviasi 1,23026. Variabel Profitabilitas mempunyai Nilai minimum -1,62 dan nilai maksimum 4,36. Rata - Rata Profitabilitas 0,4128 dengan standar deviasi 0,69107. Variabel Pertumbuhan Laba mempunyai Nilai minimum -2847 dan nilai maksimum 95. Rata - Rata Pertumbuhan Laba -46,35 dengan standar deviasi 367,845 .

\section{Uji Autokorelasi}

Tabel 2 menunjukkan bahwa nilai $d l$ dan $d u$ dapat dilihat dari tabel durbin-watson dengan $\alpha=5 \%, \mathrm{n}=$ jumlah data, $\mathrm{K}=$ jumlah variabel independen. Maka ditemukan nilai $d l=1,269$ dan nilai $d u=1,563, K=2$ dan $(\mathrm{n})=29$. Suatu model regresi tidak terdapat autokorelasi jika 4-DW lebih besar dari $d u$. Karena 4$(2,297)>1,563$, maka dapat disimpulkan tidak terdapat autokorelasi.

Tabel 1. Hasil Analisis Deskriptif

\begin{tabular}{lcrrrr}
\hline & N & Minimum & Maximum & Mean & $\begin{array}{c}\text { Std. } \\
\text { Deviation }\end{array}$ \\
\hline Aktivitas & 60 &, 51 & 5,56 & 2,1078 & 1,23026 \\
Profitabilitas & 60 & $-1,62$ & 4,36 &, 4128 &, 69107 \\
Pertumbuhan & 60 & -2847 & 95 & $-46,35$ & 367,845 \\
Laba & & & & & \\
Valid N (listwise) & 60 & & & & \\
\hline \multicolumn{5}{l}{ Sumber: Data Diolah (2021) }
\end{tabular}


Tabel 2. Hasil Uji Autokorelasi

\begin{tabular}{llllll}
\multicolumn{5}{c}{ Model Summary $^{\mathrm{b}}$} \\
\hline $\begin{array}{l}\text { Mode } \\
1\end{array}$ & $\mathrm{R}$ & R Square & $\begin{array}{l}\text { Adjusted } \\
\text { Square }\end{array}$ & $\begin{array}{l}\text { Std. Error of } \\
\text { the Estimate }\end{array}$ & Durbin-Watson \\
\hline 1 & $.763^{\mathrm{a}}$ & .582 & .550 & 1.06800 & 2.297 \\
a. Predictors: (Constant), Profitabilitas, Aktivitas \\
b. Dependent Variable: Y
\end{tabular}

Sumber: Data Diolah (2021)

Tabel 3. Analisis Regresi Linier Berganda

\begin{tabular}{lllllcc}
\multicolumn{8}{c}{ Coefficients $^{\mathrm{a}}$} \\
\hline \multicolumn{1}{c}{ Model } & Unstandardized & \multicolumn{2}{l}{ Standardized } \\
& Coefficients & Coefficients & & \\
& $\mathrm{B}$ & Std. Error & Beta & $\mathrm{T}$ & Sig. \\
\hline 1 & (Constant) & 1.588 & .467 & & 3.400 & .002 \\
& Aktivitas & -.398 & .426 & -.119 & -.935 & .358 \\
& Profitabilitas & 1.256 & .214 & .745 & 5.864 & .000 \\
\hline
\end{tabular}

a. Dependent Variable: Y

Sumber: Data Diolah (2021)

Berdasarkan Tabel 3, maka dapat disusun persamaan regresi linier berganda sebagai berikut:

$\mathrm{Y}=1,588+(-0,398) \mathrm{X}_{1}+1,256 \mathrm{X}_{2}$

Keterangan :

$\mathrm{Y}=$ Pertumbuhan Laba

a $\quad=$ Konstanta

$\beta 1 \beta 2=$ Koefisien Regresi

$\mathrm{X} 1=$ Rasio Aktivitas

$\mathrm{X} 2=$ Rasio Profitabilitas

\section{Pengujian Hipotesis}

\section{Uji Regresi Linear Berganda}

Penjelasan dari persamaan yang terdapat pada Tabel 3 adalah Konstanta (a) senilai 1,588 yang menunjukkan bahwa besarnya pengaruhvariabel independen terhadap variabel dependen yang terdiri dari aktivitas dan profitabilitas sama dengan 0 (nol) atau konstan, maka variabel independen yaitu pertumbuhan laba akan bernilai sebesar 1,588. Nilai koefisien regresi variabel aktivitas $(\beta 1)$ sebesar $(-0,398)$ dengan arah negatif menunjukkan bahwa setiap penambahan aktivitas sebesar $1 \%$, maka akan mengurangi pertumbuhan laba sebesar (-0,398). Nilai koefisien regresi variabel profitabilitas $(\beta 2)$ sebesar 1,256 dengan arahpositif menunjukkan bahwa setiap penambahan profitabilitas sebesar $1 \%$, maka akan menambah pertumbuhan laba sebesar 1,256. 
Tabel 4. Hasil Uji Simultan (Uji F)

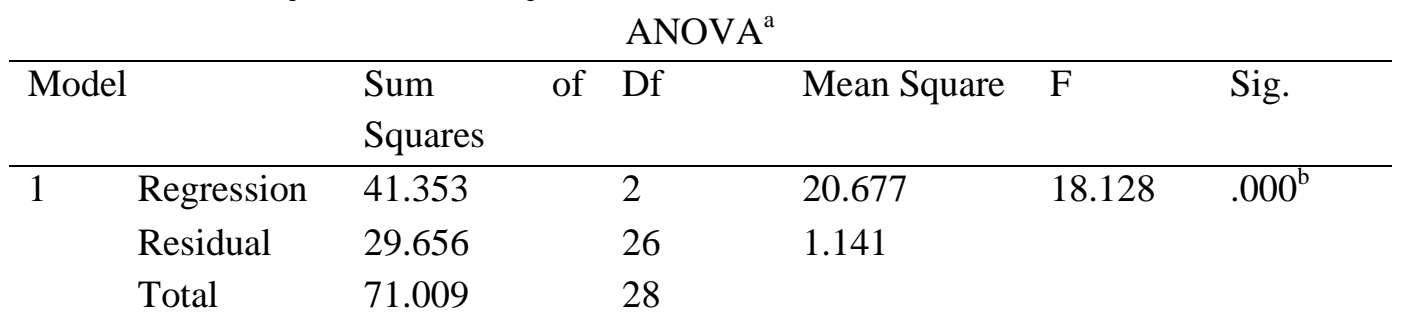

a. Dependent Variable: Y

b. Predictors: (Constant), Profitabilitas, Aktivitas

Sumber: Data Diolah (2021)

\section{Uji Simultan (Uji F)}

Berdasarkan dari tabel 4 diatas dapat diketahui bahwa nilai signifikan $F_{\text {hitung }}$ sebesar 18,128 sedangkan $\mathrm{F}_{\text {tabel }}$ (dengan tingkat kepercayaan $\alpha$ sebesar 0,05 derajat bebas regresi 2 dan derajat residualnya 26) adalah sebesar 3,37. Karena $\mathrm{F}_{\text {hitung }}$ lebih besar dari $\mathrm{F}_{\text {tabel }}$ maka $\mathrm{H}_{0}$ ditolak dan $\mathrm{H}_{1}$ diterima, dengan signifikan sebesar $0,000<0,05$ sehingga dapat disimpulkan bahwa variabel independen Aktivitas dan Profitabilitas secara simultan atau bersama-sama berpengaruh positif dan signifikan terhadap Pertumbuhan Laba.

\section{Uji Parsial T (Uji t)}

Berdasarkan Tabel 5 menunjukkan dapat diketahui bahwa Pengujian variabel Aktivitas $\left(\mathrm{X}_{1}\right)$ diperoleh $\beta_{\text {aktivitas }}=(-0,398)$, nilai $\mathrm{t}_{\text {hitung }}=(-0,119)<\mathrm{t}_{\text {tabel }}=2,051$, dengan nilai signifikan t sebesar 0,358>0,05 (5\%). Maka $\mathrm{H}_{0}$ diterima $\mathrm{H}_{1}$ ditolak dapat disimpulkan bahwa pengujian tersebut menunjukkan bahwa variabel Aktivitas menggunakan TATO dan FATOsecara parsial berpengaruh tidak signifikan terhadap variabel Pertumbuhan Laba (Y).

Pengujian variabel Profitabilitas $\left(\mathrm{X}_{2}\right)$ diperoleh $\beta_{\text {Profitabilitas }}=1,256$, nilai $\mathrm{t}_{\text {hitung }}=5,864>\mathrm{t}_{\text {tabel }}=2,051$, serta niai signifikan $\mathrm{t}$ sebesar $0,000<0,05(5 \%)$. Maka $\mathrm{H}_{0}$ ditolak $\mathrm{H}_{1}$ diterima dapat disimpulkan bahwa pengujian tersebut menunjukkan bahwa variabel Profitabilitas dengan menggunakan proxy ROA, ROE, ROI, GPM, NPM secara parsial berpengaruh signifikan terhadap terhadap variabel Pertumbuhan Laba (Y). Variabel independen yaitu aktivitas dan profitabilitas sebesar $58,2 \%$ sedangkan sisanya $41,8 \%$ dipengaruhi oleh variabel lainnya.

\section{Pengukuran Variabel Dominan}

Tabel 6 menunjukkan dapat diketahui bahwa variabel bebas Profitabilitas 0,745 dengan demikian variabel Profitabilitas merupakan variabel dominan yangmempengaruhi Pertumbuhan Laba, karena memiliki $\beta$ (beta) tertinggi sebesar 0,745 dibandingkan dengan variabel bebas yang lain. Selain itu dapat diketahui juga bahwa nilai $t_{\text {hitung }}$ variabel rasio Profitabilitas perusahaaan sebesar 5,864 yang diperkuat nilai signifikan $0,000<0,05$. 
Tabel 5. Hasil Uji Parsial (Uji t)

\begin{tabular}{|c|c|c|c|c|c|}
\hline & \multicolumn{4}{|c|}{ Coefficients $^{\mathrm{a}}$} & \multirow{4}{*}{ Sig. } \\
\hline \multirow[t]{3}{*}{ Model } & \multirow{2}{*}{\multicolumn{2}{|c|}{$\begin{array}{l}\text { Unstandardized } \\
\text { Coefficients }\end{array}$}} & Standardized & $\mathrm{t}$ & \\
\hline & & & Coefficients & & \\
\hline & B & Std. Error & Beta & & \\
\hline \multirow{3}{*}{$\begin{array}{l}\text { (Constant) } \\
\text { Aktivitas }\end{array}$} & 1.588 & .467 & & 3.400 & .002 \\
\hline & -.398 & .426 & -.119 & -.935 & .358 \\
\hline & 1.256 & .214 & .745 & 5.864 & .000 \\
\hline
\end{tabular}

a. Dependent Variable: Y

Sumber: Data Diolah (2021)

Tabel 6. Hasil Uji Variabel Dominan

Coefficients $^{\mathrm{a}}$

\begin{tabular}{|c|c|c|c|c|c|}
\hline \multirow[t]{2}{*}{ Model } & \multicolumn{2}{|c|}{$\begin{array}{l}\text { Unstandardized } \\
\text { Coefficients }\end{array}$} & $\begin{array}{l}\text { Standardized } \\
\text { Coefficients }\end{array}$ & $\mathrm{T}$ & Sig. \\
\hline & B & Std. Error & Beta & & \\
\hline (Constant) & 1.588 & .467 & & 3.400 & .002 \\
\hline Aktivitas & -.398 & .426 & -.119 & -.935 & .358 \\
\hline Profitabilitas & 1.256 & .214 & .745 & 5.864 & .000 \\
\hline
\end{tabular}

a. Dependent Variable: Y

Sumber: Data Diolah (2021)

Tabel 6 dapat diketahui bahwa variabel bebas Profitabilitas 0,745 dengan demikian variabel Profitabilitas merupakan variabel dominan yang mempengaruhi Pertumbuhan Laba, karena memiliki $\beta$ (beta) tertinggi sebesar 0,745 dibandingkan dengan variabel bebas yang lain. Selain itu dapat diketahui juga bahwa nilai $t_{\text {hitung }}$ variabel rasio Profitabilitas perusahaaan sebesar 5,864 yang diperkuat nilai signifikan $0,000<0,05$.

\section{SIMPULAN}

Berdasarkan hasil penelitian dari persamaan regresi linier bergandamengenai pengaruh variabel independen Aktivitas (X1) dan Profitabilitas (X2) terhadap variabel dependen Pertumbuhan Laba (Y) dapat disimpulkan bahwa: (1) Berdasarkan hasil uji F (Simultan) diketahui nilai signifikan $F_{\text {hitung }}$ sebesar 18,128 sedangkan $\mathrm{F}_{\text {tabel }}$ (dengan tingkat kepercayaan $\alpha$ sebesar 0,05 derajat bebas regresi 2 dan derajat residualnya 26) adalah sebesar 3,37. Karena $F_{\text {hitung }}$ lebih besar dari $\mathrm{F}_{\text {tabel }}$ maka $\mathrm{H}_{0}$ ditolak dan $\mathrm{H}_{1}$ diterima, dengan signifikan sebesar $0,000<0,05$ sehingga dapat disimpulkan bahwa variabel independen Aktivitas dan Profitabilitas secara simultan atau bersama-sama berpengaruh positif dan signifikan terhadap Pertumbuhan Laba. Dari hasil uji F (simultan) diperoleh keterangan bahwa hasil ini mengindikasikan naik turunnya laba pada perusahaan otomotif dan komponen yang tedapat di Bursa Efek Indonesia tergantung oleh naik turunnya aktivitas dan profitabilitas yang dimiliki perusahaan-perusahaan 
tersebut. (2) Pengujian variabel Aktivitas (X1). Pada uji parsial (uji t) diperoleh $\beta_{\text {aktivitas }}=(-0,398)$, nilai $\mathrm{t}_{\text {hitung }}=(-0,119)<\mathrm{t}_{\text {tabel }}=2,051$, dengan nilai signifikan $\mathrm{t}$ sebesar 0,358>0,05 (5\%). Maka $\mathrm{H}_{0}$ diterima $\mathrm{H}_{1}$ ditolak dapat disimpulkan bahwa pengujian tersebut menunjukkan bahwa variabel Aktivitas menggunakan TATO dan FATO secara parsial berpengaruh tidak signifikan terhadap variabel Pertumbuhan Laba (Y). (3) Pengujian variabel Profitabilitas (X2). Pada uji parsial (uji t)diperoleh $\beta_{\text {Profitabilitas }}=1,256$, nilai $\mathrm{t}_{\text {hitung }}=5,864>\mathrm{t}_{\text {tabel }}=2,051$, serta niai signifikan $\mathrm{t}$ sebesar $0,000<0,05(5 \%)$. Maka $\mathrm{H}_{0}$ ditolak $\mathrm{H}_{1}$ diterima dapat disimpulkan bahwa pengujian tersebut menunjukkan bahwa variabel Profitabilitas dengan menggunakan proxy ROA, ROE, ROI, GPM, NPM secara parsial berpengaruh signifikan terhadap terhadap variabel Pertumbuhan Laba (Y). (4) Berdasarkan hasil nilai standardized of coefficients beta untuk variabel aktivitas $\left(\mathrm{X}_{1}\right)$ sebesar $(-0,119)$ dan profitabilitas $\left(\mathrm{X}_{2}\right)$ sebesar 0,745 yang secara dominan berpengaruh yaitu rasio profitabilitas. Sehingga koefisien determinasi parsial terbesar dimiliki oleh variabel profitabilitas sebesar 0,745 .

\section{DAFTAR PUSTAKA}

Aryanto, U. R., Titisari, K. H., \& Nurlaela, S. (2018). Pengaruh Likuiditas, Leverage, Profitabilitas, Dan Aktivitas Terhadap Pertumbuhan Laba (Studi Empiris: Perusahaan Food And Beverages Yang Terdaftar Di Bursa Efek Indonesia Periode 2011-2015). Seminar Nasional IENACO, 625-631.

Enny Istanti. (2020). Evaluasi Prosedur Pengendalian Intern atas Piutang Usaha Pada PT Sps (Depo Gedangan). Akuntansi, 1(1), 1-10. https://univ45sby.ac.id/jurnal/index.php/akuntansi45

F.A, N., \& N, M. (2019). Analisis Rasio Aktivitas Dan Rasio Profitabilitas Pada Pertumbuhan Laba Di Indonesia Tahun 2013-2017. Jurnal Ecopreneur Fakultas Ekonomi, 2(1).

Ghozali, I. (2016). Aplikasi Analisis Multivariate Dengan Program SPSS. Semarang : Badan Penerbit Universitas Diponegoro.

Harahap, S. S. (2016). Analisis Kritis Laporan Keuangan. Jakata: PT Raja. Grafindo Persada.

Hery. (2015). Analisis Laporan Keuangan (1st ed.). Yogyakarta: Center For. Academic Publishing Services.

Hery. (2016). Analisis Laporan Keuangan. Jakarta: PT. Gramedia Widiasarana Indonesia.

Kasmir. (2016). Analisis Laporan Keuangan (satu). Jakarta: PT. Raja Grafindo Persada. 
Kasmir. (2018). Analisis Laporan Keuangan (Edisi Revi). Rajawali Pers.

Kusoy, N. A., \& Priyadi, M. P. (2020). Pengaruh Profitabilitas, Leverage dan Rasio Aktivitas terhadap Pertumbuhan Laba. Jurnal Ilmu dan Riset Akuntansi, 9(5).

Puspasari, M. ., Y.D, \& Sriwidodo, U. (2017). Pengaruh Current Ratio, Debt To Equity Ratio, Total Asset Turnover, Net Profit Margin dan Ukuran Perusahaan Terhadap Pertumbuhan Laba. Jurnal Ekonomi Manajemen Sumber Daya, 119-138.

Sugiyono. (2016). Metode Penelitian Kuantitatif, Kualitatif dan $R \& D$. ALFABETA.

Sugiyono. (2015). Metode Penelitian Kuantitatif, Kualitatif dan R\&D. Bandung: Alfabeta.

Sugiyono. (2017). Metode Penelitian Kuantitatif, Kualitatif, dan $R \& D$. Alfabeta. 